\title{
International sports law journal (2015) 15:1-2
}

\author{
Jack Anderson ${ }^{1}$
}

Published online: 12 May 2015

(C) T.M.C. Asser Instituut 2015

2015 is the year of anniversaries in sports law.

It is a century exactly since, in April 1915, an English football league first division match between Manchester United and Liverpool was fixed in United's favour for financial gain by a number of the players involved. 100 years later, an English league football is dealing with a series of criminal trials relating to arrests made by the UK's National Crime Agency after an investigation prompted by newspaper allegations of match fixing. In addition, a current Manchester United player, Ander Herrera, may still be called as a witness to a Spanish court hearing later this year over allegations that a match in May 2011 between Levante and his former club Real Zaragoza was illegally interfered with to ensure the latter won to avoid relegation. Herrera forcefully denies any wrongdoing.

Sports gambling and possible, related corruption have become much more sophisticated since the "fix" of 1915 , which was motivated by the fact that the footballers in question were facing a league shut down given the escalation of World War I. A recent investigation by the BBC, for instance, focused on the use of "courtsiders", who send back live data to syndicates and betting companies while tennis matches are under way. Courtsiding is linked to "inplay" betting, the purpose being to send back information faster than TV or betting companies can get the data and thus manipulate the odds on betting exchanges. The analogy is to high-frequency trading on the stock exchange where facilitated by tailored computer programmes, a micro-second advantage can translate into profit.

\footnotetext{
Jack Anderson

jack.anderson@qub.ac.uk

Queen's University, Belfast, UK
}

The BBC investigation into courtsiders claimed that 75 people were at last year's Wimbledon final, sending information back or betting on their own. It further noted that the tennis authorities, principally through its Tennis Integrity Unit, have been trying to "weed out" courtsiders for years, although tennis umpires apparently provide official score data which are used by betting companies. The BBC investigation focused on a "courtsider" who was arrested at the Australian Open, and later released. It seems that, although courtsiding is not fixing as generally understood, it does illustrate that the key to understanding gambling odds is that prior inside information of any kind remains fundamental to financial gain on the betting markets.

Changing to an anniversary of an altogether different kind, 30 years ago football faced tragedy with the Bradford City FC stadium fire which killed 56 on 11 May 1985. Recent coverage of the fire in the British media has focussed on the publication of a book suggesting that, far from being an accident as the immediate tribunal inquiry found, the fire was started by Bradford's then chairman for insurance fraud purposes. The coverage prompted the chair of the original tribunal, a former judge, to dismiss the allegations as speculative and unhelpful.

Not long after the Bradford fire, 39 spectators lost their lives at the European Cup final between Juventus and Liverpool held at the crumbling, 1920s-built Heysel stadium. According to one British journalist, "Heysel was the disgraceful culmination of more than a decade of ugly incidents involving English supporters on their European travels: Tottenham Hotspur in Rotterdam in 1974 and 1983, Leeds United in Paris in 1975, Manchester United in St Etienne in 1977, the national team in Basle in 1981 and so on until the spiral of moronic violence reached its tragic conclusion-logical in one sense, crazy in all others-in Brussels". Subsequently, English football was, 
collectively, punished with a 5-year ban on competing in UEFA competitions.

What is sometimes forgotten is that 26 spectators also stood trial and nearly half of them were found guilty of involuntary manslaughter and given a three-year prison sentence, suspended for 18 months. Jacques Georges, the UEFA president at the time, and Hans Bangerter, his general secretary, were threatened with imprisonment but eventually given conditional discharges. Albert Roosens, the former secretary-general of the Belgian Football Union was given a six-month suspended prison sentence for "regrettable negligence" with regard to ticketing arrangements. Gendarme captain Johan Mahieu, who was in charge of the policing in the stands at Heysel, was also accused of gross negligence on the day.

The spectators' trials took place in Belgium in 1989, the year of the Hillsborough stadium disaster. One of the most affecting sports law stories of the year has been the account from the inquests into the tragedy when 96 men, women and children lost their lives. The inquest is ongoing and can be followed at http://hillsboroughinquests.independent.gov. uk/.

Heysel and Hillsborough are reminders of how the physical landscape in which fans watch football has changed utterly; Jean-Marc Bosman changed football's legal landscape. It is 25 years since Bosman first decided to take legal action against his then employing club, and 20 years since the delivery of the Bosman ruling by the Court of Justice of the European Union. That anniversary in particular will be celebrated and reviewed exhaustively in this sports law year.

Looking forward, 2015 will see the coming into effect of the latest, revised edition of the World Anti-Doping Code. This edition of the International Sports Law Journal is largely dedicated to this important development. WADA's reach continues to widen and deepen. Even the richest, one-off sporting event of the year, the "super fight" between Floyd Mayweather and Manny Pacquiao, has seen an agreement between the fighters to adhere to WADA rules. In a sport that has not always been WADA-friendly (or compliant), this is a significant step. Indeed, a lack of agreement on drug testing was a major sticking point that led to the end of negotiations between the fighters in 2010, when the boxers (then in their prime) first tried to put together a fight.

Finally and as ever, I look forward to any thoughts you might have on the future direction of the International Sports Law Journal. The editorial team at ISLJ is particularly interested in ideas for special editions of the ISLJ on current topics of interest and on an individual basis we also especially welcome contributions from young scholars in the area of sports law. In all of the above, please do not hesitate to contact me if you wish to discuss further. For now, I hope that you enjoy the current issue.

Jack Anderson

Editor-in-Chief

International Sports Law Journal 